\title{
Investigation of Drivers and Determinants of Inpatient and Outpatient Satisfaction in Public Ambulatory and Hospital Departments
}

\author{
Vesna Velikj Stefanovska ${ }^{1}$, Miodraga Stefanovska-Petkovska ${ }^{2, *}$, Marjan Bojadziev², SonjaBojadzieva $^{3}$ \\ ${ }^{1}$ Department of Epidemiology and Biostatistics, Medical Faculty, University "St. Kiril and Metodij", Republic of Macedonia \\ ${ }^{2}$ Faculty for Business Economics and Management, University American College, Republic of Macedonia \\ ${ }^{3}$ University Children's Hospital Skopje, Republic of Macedonia
}

Copyright $@ 2017$ by authors, all rights reserved. Authors agree that this article remains permanently open access under the terms of the Creative Commons Attribution License 4.0 International License

\begin{abstract}
The last two decades have been marked by increased attention towards patient satisfaction as a valuable tool for quality improvement in health care organizations and delivering patient-centred care. However, few articles have investigated the factors of patient's satisfaction among outpatients and inpatients, especially in developing economies. This cross-sectional, quantitative research contributes by analysing patient satisfaction in the context of a developing country and its public health care system among 1318 patients from the Clinic for Plastic and Reconstructive Surgery in Skopje. The study had two main objectives. The first was to analyse factors that influenced patient's satisfaction. The second objective was to analyse the differences in the reported patient satisfaction between outpatients and inpatients within the Clinic for Plastic and Reconstructive Surgery in Skopje. The results indicated higher satisfaction among outpatients scores compared to inpatients. The findings confirm the importance of socio-demographic variables and health status on patient's satisfaction. Improved awareness of these factors may improve the patient experience and increase therapeutic benefits. Furthermore, this research provides an initial insight and understanding into the drivers of patient's satisfaction in the context of developing countries.
\end{abstract}

Keywords Patient Satisfaction, Inpatient, Outpatient, Clinic

\section{Background}

One of the most important attributes of a high-quality health care system is its ability to design and deliver patient-centred care and services [1, 2] thus positioning patient satisfaction as a widely used complementary health care quality metric $[3,4]$. While data on patient satisfaction from developing countries continues to increase, the review of the literature suggests only a scarce amount of data available for developing countries. A number of studies have suggested that the assessment of patient's experiences provides important data in the evaluation of the quality of health care services [5] and has been increasingly used in practice as a measure of both clinical and institutional performance [6]. It is proposed to be independent of clinical outcome when evaluating the quality of clinical services [6, 7]. There are notable examples of healthcare institutions that have used patient satisfaction as an organizational performance and quality management tool. In example, evaluation of patient satisfaction has been mandatory for all French hospitals since 1996, while for NHS trusts in England and hospitals in Germany it became mandatory since 2002 and 2005 respectively $[8,9,10]$.

According to the Donabedian's approach, the importance of measuring patient satisfaction comes from its role as an objective, outcome and contributor to care. Research has implied that patients that demonstrate higher levels of satisfaction are more likely to comply with the medical advice and treatment, adhere to the same healthcare providers and feel involved in the decision making process $[11,12]$.

Although both academia and practitioners agree on the importance of measuring patient satisfaction, the findings differ on the suggested factors that influence the satisfaction level of patients. While a number of studies have suggested that there is an association between the hospital characteristics [such as administration, management, environment and settings] and patient's characteristics [demographic and socio-economic factors and health status], with the patient satisfaction $[13,14,15]$, another strand of research has found that subjective experiences of received care and service and health status are stronger predictors of patient satisfaction compared to socio-demographic determinants [16, 17, 18]. The differences in the findings 
may be due to national and culturally constrained factors; however the literature review reveals that very few researches are done in developing countries. This research seeks to contribute to the existing scientific understanding of patient satisfaction by exploring its determinants and differences between outpatients and inpatients within a public health care facility in a developing country.

Therefore this study focuses on the outpatient and hospital facilities within the Clinic for Plastic and Reconstructive Surgery in Skopje, to answer two main questions: First, what are the drivers of patient satisfaction? Second, is there a difference in the overall patient satisfaction between patients that attend outpatient and those that attend hospital facilities?

\section{Methodology}

\section{Research Design}

The research presents a cross-sectional study, implemented in a two-month period from April to June, 2014. The study was implemented in the ambulatory and hospital department within the Clinic for Plastic and Reconstructive Surgery in Skopje.

The selection for the study location was made on the following assumptions: (1) the majority of patients gravitate within in the ambulatory and hospital department in the Clinic for Plastic and Reconstructive surgery in Skopje and (2) patients that are using the tertiary health care services, due to the need for previous examinations, already have a significant experience in utilizing health care and protection services.

\section{Sample}

Random sampling technique was used to select the research sample participants among patients who in the period April - June 2014 came for a scheduled examination or were hospitalized, at the Clinic for Plastic and Reconstructive Surgery in Skopje. A total of 1318 patients were included in the research, 769 from the outpatient's facilities and 549 inpatients. The research has a healthy response rate of $96 \%$. The following inclusion criteria were applied in the process of selection of the participants: minimum age of 18 years, use of services at the outpatient/hospital facilities Clinic for Plastic and Reconstructive Surgery and willingness to participate in the research. The following inclusion criteria were applied in the process of selection of the participants: under 18 years of age, not willing to participate in research or visible signs of anxiety. The research did not discriminate participants based on their gender, nationality and ethnic group, marital status, employment, health insurance or social and economic status.

\section{Instrument}

The questionnaire consists of two main sections. This instrument was designed based on findings and recommendations from previous referent research done in the field $[5,19,20]$ and findings from research done among patients in Republic of Macedonia [21].

The first section concerns the demographic data of the participants. The second section consists of 11 questions that measure the satisfaction of the patients with the management and conditions of the outpatient/hospital facilities within the Clinic for Plastic and Reconstructive Surgery in Skopje. Each response is collected on a five-point Likert type scale where $1=$ completely satisfied and $5=$ completely dissatisfied. The total points for all 11 questions range from 11 to 55, where a lower number indicates a higher level of patient satisfaction.

\section{Agreement}

Prior to the administration of the research, agreement was sought from the Clinic for Plastic and Reconstructive Surgery in Skopje by providing information on the envisaged purpose and procedure of the study. The participation in the research was voluntary as well as the process of recruitment of the potential research participants. Prior to administering the research, all participants were given information of the study as well as that the participation is voluntary and anonymous.

\section{Data Analyses}

First, descriptive statistics were calculated for socio-demographic data from the first section of the questionnaire. More specifically, we performed calculations of frequencies, percentages, means and standard deviations (SD). In order to compare the responses between the outpatient and the hospital group, Chi-square calculations were performed for categorical variables and a t-test for continuous variables.

Pearson Chi-square test for homogeneity, Yates corrected and Fischer's exact test was applied. In order to test the significance of the difference between variables, Student t-test and analysis of variance [ANOVA] were used as well as nonparametric tests for independent samples [Mann Whitney U-test. Multivariate logistic regression was used to determine the influence of independent variables on patient satisfaction of outpatients and inpatients. The statistical significance was determined for $\mathrm{p}<0.05$.

\section{Results}

A total of 1318 patients who in a period of three months have attended an examination or were hospitalized in the Clinic for Plastic Surgery in Skopje, were included in the survey. The respondents were divided in two main groups based on whether they had attended the outpatient facility or the hospital facility within the Clinic for Plastic Surgery. The first group is the outpatient group ( $\mathrm{N}=769)$ and the second is the hospital patient group $(\mathrm{N}=549)$. The main goal of the research was to assess and compare the level of satisfaction 
with the management and conditions of the outpatient/hospital facility of both groups of patients.

\section{Demographic Profile of the Research Participants}

The mean age of all research participants was $50,5 \pm 18$,2years, median of 52 years, minimum age of 18 years and maximum age of 91 years. In the outpatient group, the average age of the respondents was $51,2 \pm 17,7$ years, while in the hospital patents groups was $49,7 \pm 18,9$ years. The analyses indicated that in both groups the minimum age was 18 years (in accordance with the inclusion criteria) while there was a difference in the maximum age for the inpatients group which was 88 years. The analyses of the median indicated that $50 \%$ of the outpatients were older than 54 years, while $50 \%$ of the inpatients were older than 49 years. Furthermore, the statistical analyses did not indicate a statistically significant difference between the two groups regarding age (Mann-Whitney U Test $\mathrm{Z}=1,682 \mathrm{p}=0,0925$ ). Regarding the participants gender distribution, $55 \%$ of the outpatients were male compared with $47.9 \%$ from the inpatients group. The descriptive analyses showed that the majority of patients participating in the survey belonged to the Macedonian ethnic group (81,9\% in the outpatients group and $77,4 \%$ in the inpatients group), followed by the participants that belonged to the Albanian ethnic group $(15,8 \%$ in the outpatients group and $16,03 \%$ in the inpatients group). Regarding the place of residence, $65,93 \%$ and $90.89 \%$ from the outpatients and hospital patient group respectively came from cities, followed by $34,07 \%$ and $15,12 \%$ who came from villages. For $\mathrm{p}<0.05$, a statistical significant difference was observed regarding the place of residence, with a higher number of patients coming from villages in the outpatient group. In both groups of patients, the majority of respondents had high school as their highest completed educational level $(39.40 \%$ for outpatients and $59.56 \%$ for inpatients). There was a statistically significant difference between the two groups of patients regarding their completed education level. For $\mathrm{p}<0.05$, a statistically significant difference was observed between patients with primary education and high school, patients with primary education and college as well as between patients with primary education and a university degree. Regarding the number of children, the descriptive analyses showed that the average number of children for the two population groups was 3,65 $\pm 0,89$ (min.1 and max. 6). Outpatients had minimum 1 and maximum 5 family members living with them, while hospitalized patients had minimum 1 and maximum 6 members. The statistical analyses showed a significant difference between the two groups regarding the number of members in their family (Mann-Whitney U Test $\mathrm{Z}=-10,9633 ; \mathrm{p}=0,0001$ ). The average number of children among outpatient group was, $44 \pm 0,8$ and for the hospital patient group 3,92 $\pm 0,9.50 \%$ of the respondents from the outpatients and inpatients group lived with more than 3 and more than 4 members respectively.

In both groups, the majority of patients were married (73.39\% in the outpatient group and $81.60 \%$ in the inpatients group). The statistical analysis indicated a statistically significant difference regarding the marital status of the patients. For $\mathrm{p}<0.05$, a statistically significant difference was observed between the two groups of patients regarding the respondents who are married and those who respondent with "other". Regarding the employment status, $39.72 \%$ of the outpatients and $42.26 \%$ of the inpatients were employed. Consequently, $98.57 \%$ of outpatients and $98.54 \%$ of inpatients has health insurance. The majority of outpatients reported that their health status at admission was bad and 73.08\% reported a significantly improved health status at release. On the other hand, $81.97 \%$ of inpatients reported a not very bad health status at admission, with 37.89\% reporting satisfactory improvement at release. In terms of the number of previous visits to the Clinic of plastic surgery in Skopje, the average number of previous visits for the whole sample was 1,60 $\pm 0,85$ (min. 1 and max.3 visits). In the outpatients group, the number of previous visits was $1,60 \pm 0,85$ (min.1 and max.3 visits) while for the hospital

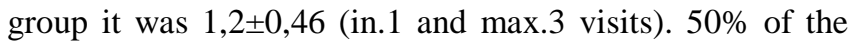
outpatients had more than two visits and $50 \%$ of the inpatients had more than one visit. For $\mathrm{p}<0.05$, a statistically significant difference was found between the two groups of patients regarding the number of previous visits to the clinic, with higher numbers observed among the outpatients group (Mann-Whitney UTest $\mathrm{Z}=12,4453 \mathrm{p}=0,001$ ). The average length of hospitalization in the Clinic for Plastic Surgery in Skopje, was 2,6 $\pm 3,5$ days for the inpatients group (min. 1 and max. 40 days). The average length of hospitalization for the male respondents was 2,34 $\pm 2,65$ days while for the female respondents it was $2,84 \pm 4,12$ days. For $p>0.05$, no statistically significant difference was observed between male and female patients regarding the length of their hospitalization. 
Table 1. Demographic profile of the survey participants

\begin{tabular}{|c|c|c|c|c|c|c|}
\hline & & \multicolumn{2}{|c|}{ Outpatients } & \multicolumn{2}{|c|}{ Inpatients } & \multirow{2}{*}{ Pearson Chi-square } \\
\hline & & $N=769$ & $\%$ & $\mathrm{~N}=549$ & $\%$ & \\
\hline \multirow{2}{*}{ Gender } & Male & 423 & 55.01 & 236 & 42.99 & \multirow{2}{*}{ Pearson Chi-square $=6,47200, \mathrm{df}=1, \mathrm{p}=0,010960$} \\
\hline & Female & 346 & 44.99 & 286 & 52.09 & \\
\hline \multirow{3}{*}{ Nationality } & Macedonian & 630 & 81.92 & 425 & 77.41 & \multirow{3}{*}{ Pearson Chi-square $=4,39281, \mathrm{df}=2, \mathrm{p}=0,111208$} \\
\hline & Albanian & 122 & 15.86 & 88 & 16.03 & \\
\hline & Other & 17 & 2.21 & 36 & 6.56 & \\
\hline \multirow{2}{*}{ Residence } & City & 507 & 65.93 & 499 & 90.89 & \multirow{2}{*}{ Pearson Chi-square $=59,5366, \mathrm{df}=1, \mathrm{p}=0,000000$} \\
\hline & Village & 262 & 34.07 & 83 & 15.12 & \\
\hline \multirow{5}{*}{ Education } & No education & 52 & 6.76 & 25 & 4.55 & Pearson Chi-square $=83,8503, \mathrm{df}=4, \mathrm{p}=0,000000$ \\
\hline & Primary & 187 & 24.32 & 138 & 25.14 & $\begin{array}{c}\text { Primary/No education - } \\
\text { Pearson Chi-square }=2,58, \mathrm{df}=1, \mathrm{p}=0,108273\end{array}$ \\
\hline & High school & 303 & 39.40 & 327 & 59.56 & $\begin{array}{c}\text { Primary/High school- } \\
\text { Pearson Chi-square }=41,24, \mathrm{df}=1, \mathrm{p}=0,00000\end{array}$ \\
\hline & College & 71 & 9.23 & 12 & 2.19 & $\begin{array}{c}\text { Primary /College- } \\
\text { Pearson Chi-square }=22,3, \mathrm{df}=1, \mathrm{p}=0,0000023\end{array}$ \\
\hline & University & 156 & 20.29 & 47 & 8.56 & $\begin{array}{c}\text { Primary /University- } \\
\text { Pearson Chi-square }=20,47, \mathrm{df}=1, \mathrm{p}=0,0000061\end{array}$ \\
\hline \multirow{3}{*}{ Marital status } & Single & 135 & 17.56 & 88 & 16.03 & Pearson Chi-square $=37,3539, \mathrm{df}=2, \mathrm{p}=0,000001$ \\
\hline & Married & 549 & 71.39 & 448 & 81.60 & $\begin{array}{l}\text { Married/Single- Pearson Chi-square }=2,22, \mathrm{df}=1 \text {, } \\
\qquad \mathrm{p}=0,165382\end{array}$ \\
\hline & Other & 85 & 11.05 & 13 & 2.37 & $\begin{array}{l}\text { Married/Other- Pearson Chi-square }=36,71, d f=1 \text {, } \\
\qquad \mathrm{p}=0,000001\end{array}$ \\
\hline \multirow{4}{*}{$\begin{array}{l}\text { Employment } \\
\text { status }\end{array}$} & Student & 32 & 4.16 & 69 & 12.57 & Pearson Chi-square $=41,0838, \mathrm{df}=3, \mathrm{p}=0,000001$ \\
\hline & Employed & 306 & 39.79 & 232 & 42.26 & $\begin{array}{c}\text { Employed/Student- } \\
\text { Pearson Chi-square }=21,66, \mathrm{df}=1, \mathrm{p}=0,0000032\end{array}$ \\
\hline & Unemployed & 159 & 20.68 & 73 & 13.30 & $\begin{array}{c}\text { Employed/Unempoyed- } \\
\text { Pearson Chi-square }=9,21, \mathrm{df}=1, \mathrm{p}=0,00241\end{array}$ \\
\hline & Retired & 272 & 35.37 & 175 & 31.88 & $\begin{array}{c}\text { Employed/Retired- } \\
\text { Pearson Chi-square=1,59, df }=1, \mathrm{p}=0,207432\end{array}$ \\
\hline \multirow{2}{*}{ Health insurance } & Yes & 758 & 98.57 & 541 & 98.54 & \multirow{2}{*}{ Pearson Chi-square $=0,001615, \mathrm{df}=1, \mathrm{p}=0,967943$} \\
\hline & No & 11 & 1.43 & 8 & 1.46 & \\
\hline \multirow{4}{*}{$\begin{array}{l}\text { Health status at } \\
\text { admission }\end{array}$} & Not very bad & 41 & 5.33 & 450 & 81.97 & \multirow{4}{*}{ Pearson Chi-square $=835,215, \mathrm{df}=3, \mathrm{p}=0,000001$} \\
\hline & Average & 192 & 24.97 & 66 & 12.02 & \\
\hline & Bad & 358 & 46.55 & 14 & 2.55 & \\
\hline & Extremely bad & 178 & 23.15 & 19 & 3.46 & \\
\hline \multirow{5}{*}{$\begin{array}{l}\text { Health status at } \\
\text { release }\end{array}$} & No improvement & 9 & 1.17 & 28 & 5.10 & \multirow{5}{*}{ Pearson Chi-square $=288,868, \mathrm{df}=4, \mathrm{p}=0,000001$} \\
\hline & $\begin{array}{c}\text { Small } \\
\text { improvement }\end{array}$ & 31 & 4.03 & 119 & 21.68 & \\
\hline & I don't know & 39 & 5.07 & 43 & 7.83 & \\
\hline & $\begin{array}{c}\text { Satisfactory } \\
\text { improvement }\end{array}$ & 128 & 16.64 & 208 & 37.89 & \\
\hline & $\begin{array}{l}\text { Significantly } \\
\text { improved }\end{array}$ & 562 & 73.08 & 151 & 27.50 & \\
\hline
\end{tabular}

\section{Patient Satisfaction}

The following section presents the analyses of the results gathered from 1318 patients in outpatient and hospital facilities within the Clinic for plastic surgery in Skopje, regarding their satisfaction with the conditions and management of the facility that enables them to adequately utilize their health care protection. A total of 11 questions were included in the analyses and all answers were recorder on a five point Likert type scale (where 1=Very satisfied and
$5=$ Very dissatisfied). A reliability analysis was conducted on the recorded responses from the two patient groups by calculating Cronbach's alpha coefficient. Regarding the outpatient Cronbach's Alpha $=0,814$, and for the hospital patient group Cronbach's Alpha $=0,922$, both results indicating high validity of the responses from the two groups. Table 1 presents the satisfaction levels of both groups of patients regarding on all eleven items. The majority of outpatients (35.89\%) are very satisfied and the majority of 
inpatients are satisfied (72.50\%) with the system for scheduling an exam. $52.80 \%$ of the outpatients were very satisfied with the respect for the scheduled exam time, while $71.95 \%$ of the inpatients said they were satisfied. In regards to the location of the Clinic for plastic surgery, $72.43 \%$ of the outpatients said they were very satisfied with the location while $62.30 \%$ of the inpatients said they were satisfied. In general, the majority of patients from both groups responded that they were satisfied with the accessibility of the outpatient/ hospital facility, with $72.56 \%$ of the outpatients responding very satisfied and $57.38 \%$ of the inpatients responding as satisfied. Regarding the hygiene in the facility they attended, $91,94 \%$ of the outpatients gave a positive response $(24.88 \%$ were very satisfied and $37.06 \%$ were satisfied) while $81.27 \%$ responding positively from the hospital patient group (35.70\% were very satisfied and $46.27 \%$ were satisfied). A total of $45.94 \%$ of the patients in both groups were very satisfied with the conditions for waiting in the facility, followed by $40.09 \%$ who were satisfied. In terms of the conditions for performing the exam, $54.78 \%$ of patients from both groups reported that they were very satisfied followed by $38.69 \%$ who were satisfied. Only $3.89 \%$ of both patient groups reported that they were not satisfied. A strong majority of $72.69 \%$ of all outpatients reported that they were very satisfied with the technical equipment and medications that are used to perform the exam. The smaller majority (59.02\%) of the group of inpatients said they were satisfied. A similar distribution of answers is noted in the following two statements regarding the information on required documentation for the exam and the satisfaction with the hygiene in the toilets. The majority of the outpatients responded that they are very satisfied with the transparency of the information for required documents for the exam and the hygiene of the toilet $(73.08 \%$ and $56.44 \%$ respectively) followed by the majority of the inpatients groups who said they were satisfactory (62.84\% and $45.17 \%$ respectively)

As presented in Table 2 , for $\mathrm{p}<0,05$, there is a statistically significant difference between the two groups of patients regarding all eleven items, with higher satisfaction scores recorded among the group of outpatients.

Table 2. Satisfaction with conditions and management with hospital premises by patient group

\begin{tabular}{|c|c|c|c|c|c|c|c|c|c|c|c|c|}
\hline \multirow{2}{*}{ Statement } & \multirow{2}{*}{$\begin{array}{l}\text { Patient } \\
\text { group }\end{array}$} & \multicolumn{2}{|c|}{ Very satisfied } & \multicolumn{2}{|c|}{ Satisfied } & \multicolumn{2}{|c|}{ Not certain } & \multicolumn{2}{|c|}{ Dissatisfied } & \multicolumn{2}{|c|}{$\begin{array}{c}\text { Very } \\
\text { dissatisfied }\end{array}$} & \multirow{2}{*}{$\begin{array}{l}\text { Pearson } \\
\text { Chi-square }\end{array}$} \\
\hline & & $\mathrm{N}$ & $\%$ & $\mathrm{~N}$ & $\%$ & $\mathrm{~N}$ & $\%$ & $\mathrm{~N}$ & $\%$ & $\mathrm{~N}$ & $\%$ & \\
\hline \multirow{2}{*}{$\begin{array}{c}\text { System for } \\
\text { scheduling an exam }\end{array}$} & Outpatients & 276 & 35,89 & 348 & 45,25 & 115 & 14,95 & 25 & 3,25 & 5 & 0,65 & \multirow{2}{*}{$\begin{array}{c}114.843 \mathrm{df}=4, \\
\mathrm{p}=0.0000\end{array}$} \\
\hline & $\begin{array}{c}\text { Hospital } \\
\text { patients }\end{array}$ & 106 & 19,31 & 398 & 72,5 & 19 & 3,46 & 23 & 4,19 & 3 & 0,55 & \\
\hline \multirow{2}{*}{$\begin{array}{l}\text { Respecting the } \\
\text { scheduled time for } \\
\text { exam }\end{array}$} & Outpatients & 406 & 52,8 & 319 & 41,48 & 36 & 4,68 & 8 & 1,04 & 0 & 0 & \multirow{2}{*}{$\begin{array}{c}161,946 \mathrm{df}=4, \\
\mathrm{p}=0.0000\end{array}$} \\
\hline & $\begin{array}{c}\text { Hospital } \\
\text { patients }\end{array}$ & 105 & 19,13 & 395 & 71,95 & 27 & 4,92 & 19 & 3,46 & 3 & 0.55 & \\
\hline \multirow{2}{*}{$\begin{array}{c}\text { Information on } \\
\text { location of } \\
\text { hospital/outpatient } \\
\text { premises }\end{array}$} & Outpatients & 557 & 72,43 & 202 & 26,27 & 10 & 1,3 & 0 & 0 & 0 & 0 & \multirow{2}{*}{$\begin{array}{c}329,490 \mathrm{df}=4, \\
\mathrm{p}=0.0000\end{array}$} \\
\hline & $\begin{array}{c}\text { Hospital } \\
\text { patients }\end{array}$ & 129 & 23,5 & 342 & 62,3 & 57 & 10,38 & 15 & 2,73 & 6 & 1,09 & \\
\hline \multirow{2}{*}{$\begin{array}{c}\text { Convenience of } \\
\text { location of } \\
\text { hospital/outpatient } \\
\text { premises }\end{array}$} & Outpatients & 558 & 72,56 & 203 & 26,4 & 6 & 0,78 & 2 & 0.26 & 0 & 0 & \multirow{2}{*}{$\begin{array}{c}276,524 \mathrm{df}=4, \\
p=0.0000\end{array}$} \\
\hline & $\begin{array}{l}\text { Hospital } \\
\text { patients }\end{array}$ & 157 & 28,6 & 315 & 57,38 & 57 & 10,38 & 12 & 2,19 & 8 & 1,46 & \\
\hline \multirow{2}{*}{$\begin{array}{c}\text { Hygiene in the } \\
\text { hospital/outpatient } \\
\text { premises }\end{array}$} & Outpatients & 422 & 54,88 & 285 & 37,06 & 51 & 6,63 & 8 & 1,04 & 3 & 0,39 & \multirow{2}{*}{$\begin{array}{c}59,0551 \mathrm{df}=4 \\
\mathrm{p}=0.0000\end{array}$} \\
\hline & $\begin{array}{c}\text { Hospital } \\
\text { patients }\end{array}$ & 196 & 35,7 & 254 & 46,27 & 75 & 13,66 & 15 & 2,73 & 9 & 1,64 & \\
\hline \multirow{2}{*}{$\begin{array}{l}\text { Waiting time for } \\
\text { scheduled exam }\end{array}$} & Outpatients & 419 & 54,49 & 246 & 31,99 & 59 & 7,67 & 28 & 3,64 & 17 & 2,21 & \multirow{2}{*}{$\begin{array}{c}64,8885 \mathrm{df}=4 \\
\mathrm{p}=0.0000\end{array}$} \\
\hline & $\begin{array}{c}\text { Hospital } \\
\text { patients }\end{array}$ & 186 & 33,88 & 282 & 51,37 & 58 & 10,56 & 13 & 2,37 & 9 & 1,64 & \\
\hline \multirow{2}{*}{$\begin{array}{l}\text { Conditions of the } \\
\text { premises where the } \\
\text { exam is performed }\end{array}$} & Outpatients & 530 & 68,92 & 229 & 29,78 & 9 & 1,17 & 1 & 0,13 & 0 & 0 & \multirow{2}{*}{$\begin{array}{c}183,486 \\
\mathrm{df}=4, \\
\mathrm{p}=0.0000\end{array}$} \\
\hline & $\begin{array}{l}\text { Hospital } \\
\text { patients }\end{array}$ & 192 & 34,97 & 281 & 51,18 & 52 & 9,47 & 15 & 2,73 & 9 & 1,64 & \\
\hline \multirow{2}{*}{$\begin{array}{l}\text { Technical equipment } \\
\text { and medications }\end{array}$} & Outpatients & 559 & 72,69 & 200 & 26,01 & 10 & 1,2 & 1 & 0,13 & 0 & 0 & \multirow{2}{*}{$\begin{array}{c}280,979+\mathrm{M} 35 \\
\mathrm{df}=4, \\
\mathrm{p}=0.0000\end{array}$} \\
\hline & $\begin{array}{c}\text { Hospital } \\
\text { patients }\end{array}$ & 153 & 27,87 & 324 & 59,02 & 47 & 8,56 & 18 & 3,28 & 7 & 1,28 & \\
\hline \multirow{2}{*}{$\begin{array}{l}\text { Timely information } \\
\text { and required } \\
\text { documentation from } \\
\text { patients }\end{array}$} & Outpatients & 562 & 73,08 & 192 & 24,97 & 11 & 1,43 & 4 & 0,52 & 0 & 0 & \multirow{2}{*}{$\begin{array}{c}328,337 \mathrm{df}=4, \\
\mathrm{p}=0.0000\end{array}$} \\
\hline & $\begin{array}{c}\text { Hospital } \\
\text { patients }\end{array}$ & 129 & 23,5 & 345 & 62,84 & 56 & 10,2 & 13 & 2,37 & 6 & 1,09 & \\
\hline \multirow{2}{*}{$\begin{array}{l}\text { Hygiene and } \\
\text { availability of the } \\
\text { toilets }\end{array}$} & Outpatients & 434 & 56,44 & 194 & 25,23 & 85 & 11,05 & 30 & 3,9 & 26 & 3,38 & \multirow{2}{*}{$\begin{array}{c}64,8262 \mathrm{df}=4, \\
\mathrm{p}=0.0000\end{array}$} \\
\hline & $\begin{array}{c}\text { Hospital } \\
\text { patients }\end{array}$ & 216 & 39,34 & 248 & 45,17 & 63 & 11,48 & 16 & 2,91 & 6 & 1,09 & \\
\hline
\end{tabular}


Descriptive analyses of the research data was conducted in order to understand and compare the level of satisfaction of patents from both groups regarding the hospital conditions and management (see Table 3). The results suggested that outpatients demonstrate an overall satisfaction score ranging between 11 and 32 points. Approximately 50\% of the outpatients reported a satisfactions score that is higher than 15 points. The average satisfaction level of outpatients with conditions and management of the outpatients facility is $16,15 \pm 4,37$. Regarding inpatients, the satisfaction score ranges from 11 to 55 , with $50 \%$ of the respondents in this group reporting a score higher than 20 points. The average satisfaction level of inpatients with hospital conditions and management is $20,79 \pm 6,33$. The results suggest that patients are generally satisfied with the hospital environment and management with significantly higher scores among outpatients (t-test $=-15,7350 ; \mathrm{df}=1316 ; \mathrm{p}=0,0001$ ).

Table 3 and Table 4 present the demographic differences in the average satisfaction score from the conditions and management of outpatient and hospital facilities. The bivariate analyses indicated that there is no significant difference in the average satisfaction score among outpatients in regards to age, work status, nationality, place of residence, number of visits and doctor's gender. However, a significant difference was found in regards to patient's gender, marriage status, education, number of family members, health status at the time of admission and the health status after treatment.

Table 3. Descriptive analyses of patient satisfaction levels regarding conditions and management in the public health care facility

\begin{tabular}{|c|c|c|c|c|c|c|}
\hline Group & Number & Mean & St. dev. & Median & Minimum & Maximum \\
\hline Outpatients & 769 & $1,615,085$ & $4,370,310$ & 15 & 11 & 32 \\
\hline Inpatients & 549 & $2,078,871$ & $6,329,385$ & 20 & 11 & 55 \\
\hline Total & 1318 & $1,808,270$ & $5,747,931$ & 18 & 11 & 55 \\
\hline t-test for independent samples=-15,7350; df=1316; $\mathrm{p}=0,0001$
\end{tabular}

Table 4. Overall satisfaction score by socio-demographic characteristics and patient group

\begin{tabular}{|c|c|c|c|c|c|c|}
\hline \multirow{3}{*}{ Demographic variable } & \multicolumn{3}{|c|}{ Overall satisfaction score } & \multicolumn{3}{|c|}{ Overall satisfaction score } \\
\hline & \multicolumn{3}{|c|}{ Outpatient } & \multicolumn{3}{|c|}{ Inpatients } \\
\hline & Mean & SD & $\mathrm{p}$ & Mean & SD & $\mathrm{p}$ \\
\hline \multicolumn{7}{|c|}{ Gender } \\
\hline Male & $1,644,917$ & $4,591,012$ & $\mathrm{t}=2,0977$ & $2,104,183$ & $7,200,122$ & $t=-0,8984$ \\
\hline Female & $1,578,613$ & $4,061,189$ & $\begin{array}{c}\mathrm{df}=767 ; \\
\mathrm{p}=0,0363^{*}\end{array}$ & $2,055,594$ & $5,409,091$ & $\mathrm{df}=547 ; \mathrm{p}=0,3594$ \\
\hline \multicolumn{7}{|c|}{ Marital status } \\
\hline Single & $1,661,481$ & $4,460,415$ & ANOVA & $2,038,636$ & $6,073,178$ & ANOVA \\
\hline Married & $1,588,525$ & 4,331,132 & $\mathrm{F}=3,935$ & $2,091,295$ & $6,435,292$ & $\mathrm{~F}=0,657$ \\
\hline Other & $1,712,941$ & $4,328,170$ & $\mathrm{df}=2 ; \mathrm{p}=0,0199 *$ & $1,923,077$ & $3,876,292$ & $\mathrm{df}=2 ; \mathrm{p}=0,5188$ \\
\hline \multicolumn{7}{|c|}{ Education } \\
\hline No education & $1,611,538$ & $4,617,332$ & ANOVA & $2,012,000$ & $6,572,164$ & ANOVA \\
\hline Primary school & $1,518,182$ & 4,296,672 & $F=7,866$ & $2,125,362$ & $7,071,131$ & $\mathrm{~F}=0,840$ \\
\hline High school & $1,580,198$ & $4,067,363$ & $\mathrm{df}=4 ; \mathrm{p}=0,0001^{* *}$ & $2,048,930$ & $6,087,731$ & $\mathrm{df}=4 ; \mathrm{p}=0,5000$ \\
\hline College & $1,747,887$ & $4,696,075$ & & $2,283,333$ & $8,684,713$ & \\
\hline University degree & $1,739,744$ & $4,419,428$ & & $2,134,043$ & $4,710,195$ & \\
\hline \multicolumn{7}{|c|}{ Employment status } \\
\hline Student & $1,671,875$ & $4,049,965$ & ANOVA & $2,014,493$ & $6,866,961$ & ANOVA \\
\hline Employed & $1,619,608$ & $4,133,920$ & $\mathrm{~F}=0,360$ & $2,090,517$ & $6,235,603$ & $\mathrm{~F}=0,277$ \\
\hline Unemployed & $1,590,566$ & $4,444,870$ & $\mathrm{df}=3 ; \mathrm{p}=0,7819$ & $2,079,452$ & $6,383,483$ & $\mathrm{df}=3 ; \mathrm{p}=0,8422$ \\
\hline Retired & $1,617,647$ & $4,628,457$ & & $2,088,571$ & $6,250,386$ & \\
\hline \multicolumn{7}{|c|}{ Nationality } \\
\hline Macedonian & $1,618,571$ & $4,274,610$ & ANOVA & $2,088,471$ & $6,510,759$ & ANOVA \\
\hline Albanian & $1,577,049$ & $4,839,211$ & $\mathrm{~F}=1,403$ & $1,986,364$ & $4,768,628$ & $\mathrm{~F}=0,564$ \\
\hline Other & $1,758,824$ & $4,243,507$ & $\mathrm{df}=2 ; \mathrm{p}=0,2465$ & $2,191,667$ & $7,322,665$ & $\mathrm{df}=2 ; \mathrm{p}=0,2103$ \\
\hline
\end{tabular}




\begin{tabular}{|c|c|c|c|c|c|c|}
\hline \multicolumn{7}{|c|}{ Place of residence } \\
\hline City & $1,633,333$ & $4,272,503$ & $t=-1,612$ & $2,080,043$ & $6,351,435$ & $t=0,103$ \\
\hline Village & $1,579,771$ & $4,541,118$ & $\mathrm{df}=767 ; \mathrm{p}=0,1073$ & $2,072,289$ & $6,241,703$ & $\mathrm{df}=547 ; \mathrm{p}=0,9182$ \\
\hline \multicolumn{7}{|c|}{ Number of previous appointments } \\
\hline First time & $1,581,167$ & $4,211,695$ & ANOVA & $2,074,893$ & $6,281,159$ & ANOVA \\
\hline Second time & $1,670,455$ & $4,737,134$ & $\mathrm{~F}=2,389$ & $2,101,538$ & $7,406,695$ & $\mathrm{~F}=0,0607$ \\
\hline Three times and more & $1,641,118$ & $4,433,447$ & $\mathrm{df}=2 ; \mathrm{p}=0,0924$ & $2,100,000$ & 2,326,320 & $\mathrm{df}=2 ; \mathrm{p}=0,9411$ \\
\hline \multicolumn{7}{|c|}{ Number of family members } \\
\hline One & $1,312,500$ & $1,962,142$ & ANOVA & $2,165,000$ & $7,464,125$ & ANOVA \\
\hline Two & $1,728,571$ & $4,413,315$ & $\mathrm{~F}=4,0011$ & $1,820,000$ & $1,923,538$ & $\mathrm{~F}=0,4473$ \\
\hline Three & $1,650,938$ & $4,375,892$ & $\mathrm{df}=4 ; \mathrm{p}=0,0032^{* *}$ & $2,012,162$ & $4,239,258$ & $\mathrm{df}=4 ; \mathrm{p}=0,8153$ \\
\hline Four & $1,574,708$ & $4,336,690$ & & $2,089,779$ & $6,760,898$ & \\
\hline Five & $1,579,012$ & $4,434,851$ & & $2,074,648$ & $6,138,214$ & \\
\hline Six or more & l & / & & $2,129,412$ & $4,606,581$ & \\
\hline \multicolumn{7}{|c|}{ Health status at time of admission } \\
\hline Not very bad & $1,809,756$ & $4,678,701$ & ANOVA & 2,095,333 & $6,509,205$ & ANOVA \\
\hline Average & $1,589,063$ & $4,111,472$ & $\mathrm{~F}=3,174$ & $2,119,697$ & $5,797,134$ & $F=2,883$ \\
\hline Bad & $1,619,274$ & 4,477,676 & $\mathrm{df}=3 ; \mathrm{p}=0,0237^{*}$ & $1,707,143$ & $2,644,713$ & $\mathrm{df}=3 ; \mathrm{p}=0,0353^{*}$ \\
\hline Extremely bad & $1,589,888$ & $4,269,310$ & & $1,821,053$ & $4,157,710$ & \\
\hline \multicolumn{7}{|c|}{ Improvement of health status at release } \\
\hline No improvement & $1,288,889$ & $2,934,469$ & ANOVA & $1,928,571$ & $5,830,044$ & ANOVA \\
\hline Small improvement & $1,738,710$ & 3,499,309 & $\mathrm{F}=10,802$ & $1,921,008$ & $2,863,783$ & $\mathrm{~F}=3,177$ \\
\hline I don't know & $1,935,897$ & $4,901,596$ & $\mathrm{df}=4 ; \mathrm{p}=0,0001^{* *}$ & $2,158,140$ & $5,399,438$ & $\mathrm{df}=4 ; \mathrm{p}=0,0135^{*}$ \\
\hline $\begin{array}{c}\text { Satisfactory } \\
\text { improvement }\end{array}$ & $1,712,500$ & $4,190,353$ & & $2,121,154$ & $6,827,301$ & \\
\hline Significantly improved & $1,569,039$ & $4,285,724$ & & $2,150,331$ & $7,613,036$ & \\
\hline \multicolumn{7}{|c|}{ Gender of doctor } \\
\hline Male & $1,599,289$ & $4,204,674$ & $\mathrm{t}=-1,105$ & $2,042,222$ & $6,046,335$ & $\mathrm{t}=0,947$ \\
\hline Female & $1,634,294$ & $4,562,409$ & $\mathrm{df}=767 ; \mathrm{p}=0,2693$ & $2,096,748$ & $6,463,444$ & $\mathrm{df}=547 ; \mathrm{p}=0,3438$ \\
\hline \multicolumn{2}{|c|}{ *significant for $\mathrm{p}<0,05$} & & \multicolumn{3}{|c|}{$* *$ significant for $\mathrm{p}<0,01$} & \\
\hline
\end{tabular}

Table 5. Results from the multiple regression analysis on satisfaction from conditions and management among outpatients and inpatients

\begin{tabular}{|c|c|c|c|c|}
\hline \multirow{8}{*}{ Outpatients } & \multicolumn{2}{|c|}{$\begin{array}{c}\text { Standardized coefficient } \\
\mathrm{R}^{2}=0,061 \mathrm{~F}=8,269\end{array}$} & $\mathrm{p}=0,000$ & \multirow[b]{2}{*}{$\mathbf{p}$} \\
\hline & Independent variable & Beta & $\mathbf{t}$ & \\
\hline & Gender &,- 081 & $-2,275$ & ,023* \\
\hline & Education & ,192 & 5,222 &, $000 *$ \\
\hline & Marital status &,- 036 &,- 969 & ,333 \\
\hline & Health status during admission &,- 063 & $-1,789$ & ,074 \\
\hline & Number of family members &,- 025 &,- 704 & ,482 \\
\hline & Health status at release &,- 143 & $-4,045$ &, $000 *$ \\
\hline \multirow{4}{*}{ Inpatients } & \multicolumn{3}{|c|}{ Standardized coefficient } & \\
\hline & Independent variable & Beta & $\mathbf{t}$ & $\mathbf{p}$ \\
\hline & Health status during admission &,- 079 & $-1,863$ & ,063 \\
\hline & Health status at release & ,124 & 2,908 & ,004 \\
\hline
\end{tabular}

* significant for $\mathrm{p}<0,05$ 
All the variables that were found as significant in the bivariate analyses, were included in the multivariate regression analysis, using the enter method. The results presented in Table 5 suggest that gender, education and the health status of the outpatient after the treatment were significant independent predictors of the satisfaction with conditions and management among outpatients. The results of the multiple regression analyses showed that $6.1 \%$ $\left(R^{2}=0,061\right)$ of the variance in the dependent variable is explained by the six independent variables, while $5.1 \%$ of the variance in the dependent variable is explained by the three independent significant predictors - gender, education and health status of the outpatient after treatment. (Stepwise method - $\mathrm{R}^{2}=0,051$ ).

Concerning the group of inpatients, a significant difference in the satisfaction score was found regarding the health status of patient during admission and the health status of the patient at release from the hospital $(\mathrm{p}<0,05)$. These two variables were included in the multivariate regression analyses (enter method) and the health status of the patient after the treatment was the only significant predictor of the satisfaction with hospital conditions and management. Additionally, the results suggested that the independent variable explain $2.4 \%$ of the variance in the satisfaction with hospital conditions and management $\left(R^{2}=0,024\right)$ while only $1.8 \%$ of the variance in the satisfaction score is explained by the health status of the patient after the treatment (Stepwise method - $\mathrm{R}^{2}=0,018$ ).

\section{Discussion and Conclusion}

As in previous studies, the results indicated that there is a significant difference in the satisfaction scores in regards to patient's gender, marital status, education level, and the health status after treatment. Regarding gender, males showed higher satisfaction levels compared to females which is consistent with findings from other studies as well [19, 20]. Similarly to previous findings, those patients that were married tended to have higher satisfaction scores [21]. The study also investigated the role of the patients education level, and found that those with higher education levels tended to have higher satisfaction levels, which is contrary to other studies where patients with no education or primary education had higher satisfaction scores [22]. Although the significance of this factors is not found in other studies [23] there is a wide consensus on the significance of the health status as an influencing factor on patient satisfaction [16, 17]. Although we found that there is a significant difference in the satisfaction scores in regards to number of family members, no previous studies with similar findings were found. The results from this study indicated that there is no significant difference in the average satisfaction score among outpatients in regards to age, employment status, nationality, place of residence, number of visits and doctor's gender. This differs from some other findings in the conducted research on patient satisfaction. In example, a number of studies have found a significant relationship between the patient's age and satisfaction [24;25] in patient satisfaction tended to increase with age. Employment status is also a variable that has been found in some studies to have a significant relationship with patient satisfaction [26]. Interestingly, two study done in Germany indicated that patients perception of care are more important determinants of patient satisfaction compared to demographic characteristics of the patients and the characteristics of the visit $[18 ; 27]$. The results from this study implied that the characteristics of the patient, mores specifically the gender, education and the health status after treatment influenced the reported patient satisfaction with the management and conditions of the health facility. More specifically, in the outpatients group, the gender, education and the health status of the outpatient after the treatment resulted as significant independent predictors of the patient satisfaction, while for inpatients it was only the health status after treatment. Although the role of some of these variables on patient satisfaction have been included previously in other studies, the conducted review of the literature revealed that this is the first attempt to study such variables together in a multivariate analyses within a large sample from a developing country.

Browne [28] argued that measuring patient satisfaction provides a powerful quality improvement tool. However, one of the limitation in this study, as well as other studies performed in the field, is the low $\mathrm{R}^{2}$ values which may suggest that we dot fully understand the factors that are associated with patient satisfaction [30, 31]. Therefore, patient satisfaction measures should be balanced off with the benefits from truthful therapeutic discourse to provide beneficial effects on health care utilization and outcomes. At the same time, this allows room for future research to include variables that have not been investigated and that may potentially improve the prediction of patient satisfaction. Finally, since patient satisfaction has become a pivotal toll in the quality assessment of health care in developing countries, unfortunately there is still scarce amount of research from developing countries. To overcome this gap, this study provided evidence that could lead to increased awareness about the level and determinants of patient's satisfaction in the developing countries [32].

\section{REFERENCES}

[1] L.T. Kohn, J.M. Corrigan, M.S. Donaldson. To Err is Human: Building a Safer Health System, Institute of Medicine [US] Committee on Quality of Health Care in America, Washington [DC]: National Academies Press [US]; 2000.

[2] T.C. Tsai, E.J. Orav, A.K. Jha. Patient satisfaction and quality of surgical care in US hospitals. Annals of surgery, 261[1]:2, 2015.

[3] K. Brown, D. Roseman, D. Shaller, S. Edgman-Levitan. Analysis \& commentary measuring patient experience as a strategy for improving primary care. Health 
Affairs,1;29[5]:921-5, 2010.

[4] J.J. Fenton, A.F. Jerant, K.D. Bertakis, P. Franks. The cost of satisfaction: a national study of patient satisfaction, health care utilization, expenditures, and mortality, Archives of internal medicine, 12;172[5], pp. 405-11.2015

[5] E.L. Wong, A. Coulter, P. Hewitson, A.W. Cheung, C.H. Yam, S. fai Lui, W.W. Tam, E.K. Yeoh. Patient experience and satisfaction with inpatient service: development of short form survey instrument measuring the core aspect of inpatient experience. PloS one. 10;10[4], 2015.

[6] S. Waters, S.J. Edmondston, P.J. Yates, D.F. Gucciardi. Identification of factors influencing patient satisfaction with orthopaedic outpatient clinic consultation: A qualitative study. Manual Therapy. 30;25, pp.48-55, 2016.

[7] R.J. Butler, W.G. Johnson. Satisfaction with low back pain care. The spine journal. 30;8[3], pp.510-21, 2008.

[8] KA Marley, DA Collier, S Meyer Goldstein. The Role of Clinical and Process Quality in Achieving Patient Satisfaction in Hospitals, Decision Sciences, Vol: 35, NO. 3, pp. 349-369.2004.

[9] S. Tonio, K. Joerg,K. Joachim. Determinants of patient satisfaction: a study among 39 hospitals in an in-patient setting in Germany. International Journal for Quality in Health Care, 23[5], pp. 503-509, 2011.

[10] J. Crispin, C. Angela, B. Stephen. The Picker Experience Questionnaire development and validation using data from in-patient surveys in five countries, International journal of quality in Health Care, Vol: 14 No. 5, pp.353-358. 2002.

[11] L.C. Sarah, J. Lei, L. Wendy, O.M. David. Does Doctor-Patient Communication Affect Patient Satisfaction with Hospital Care: Results of an Analysis with a Novel Instrumental Variable? Health Science Research, 43 [5]. 2008.

[12] Al-Abri and Al-Balushi. Patient satisfaction as a tool towards quality improvement, Oman Med Journal, 29,1, pp. 3-7, 2014

[13] J.L. Hargraves, I.B. Wilson, A. Zaslavsky, C. James, J.D. Walker, G. Rogers, P.D. Cleary. Adjusting for patient characteristics when analyzing reports from patients about hospital care. Medical care. 1;39[6], pp. 635-41, 2001.

[14] C.K. Jaipaul, G.E. Rosenthal. Do hospitals with lower mortality have higher patient satisfaction? A regional analysis of patients with medical diagnoses. American Journal of Medical Quality. 18[2], pp.59-65. 2003

[15] L.H. Aiken, W Sermeus, K. Van den Heede, D.M. Sloane, R. Busse, M. McKee, L. Bruyneel, A.M. Rafferty, P. Griffiths, M.T. Moreno-Casbas, C. Tishelman. Patient safety, satisfaction, and quality of hospital care: cross sectional surveys of nurses and patients in 12 countries in Europe and the United States. Bmj. 20, 34, 2012.

[16] C. Jenkinson, A. Coulter, S. Bruster, N. Richards, T. Chandola. Patients' experiences and satisfaction with health care: results of a questionnaire study of specific aspects of care. Quality and safety in health care, 1;11[4]3, pp.35-9, 2002.

[17] S.H. Cheng, M.C. Yang, T.L. Chiang. Patient satisfaction with and recommendation of a hospital: effects of interpersonal and technical aspects of hospital care.
International Journal for Quality in Health Care, 1;15[4], pp.345-55, 2003.

[18] T. Schoenfelder, J. Klewer, .J Kugler. Determinants of patient satisfaction: a study among 39 hospitals in an in-patient setting in Germany. International journal for quality in health care. 23[5], pp.503-9, 2011.

[19] J.M. Quintana, U. Aguirre, I. Barrio, M. Orive, S. Garcia, A. Escobar. Outcomes after total hip replacement based on patients' baseline status: what results can be expected?. Arthritis care \& research. 1;64[4], pp. 563-72, 2012.

[20] T.D. Shanafelt, S Boone, L Tan, LN Dyrbye, W Sotile, D Satele, CP West, J Sloan, MR Oreskovich. Burnout and satisfaction with work-life balance among US physicians relative to the general US population. Archives of internal medicine. 2012 Oct 8;172(18):1377-85.

[21] V. Velic Stefanovska. Sto mislat Romite za zdravstvenata griza. ISBN 978-9989-2734-1-4. Skopje. 2007

[22] P.L. Thi, S. Briancon, F. Empereur, F. Guillemin. Factors determining inpatient satisfaction with care. Social science \& medicine. 28, 54[4], pp.493-504, 2002.

[23] J.A. Hall, M.C. Dornan. Patient sociodemographic characteristics as predictors of satisfaction with medical care: a meta-analysis. Social science \& medicine. 1, 30[7], pp.811-8, 1990.

[24] C. Shou-Hisa, Y. Ming-Chin, C. Tung-uang. Patient Satisfaction with and recommendation of a hospital: effects of interpersonal and technical aspects of hospital care. International Journal for Quality in Health Care, 15, pp. 345-355, 2003

[25] J.L. Hargraves, I.B. Wilson, A. Zaslavsky, C. James, J.D. Walker, G. Rogers, P.D. Cleary. Adjusting for patient characteristics when analyzing reports from patients about hospital care. Medical care, 1;39[6], pp.635-41, 2001.

[26] C.K. Jaipaul, G.E. Rosenthal. Do hospitals with lower mortality have higher patient satisfaction? A regional analysis of patients with medical diagnoses. American Journal of Medical Quality. 18[2]:, pp.59-65, 2003.

[27] E.J. Beck, R. Griffith, R. Fitzpatrick, S. Mandalia, J. Carrier, C. Conlon, B. Mandel, E. Ong, A. Pozniak, A Tang, D Tomlinson. Patient satisfaction with HIV service provision in NPMS hospitals: the development of a standard satisfaction questionnaire. AIDS care, 1;11[3], pp.331-43, 1999.

[28] A.J. Schoenfeld, L.M. Ochoa, J.O. Bader, P.J. Belmont. Risk factors for immediate postoperative complications and mortality following spine surgery: a study of 3475 patients from the National Surgical Quality Improvement Program. J Bone Joint Surg Am. 7, 93[17], pp.1577-82, 2011.

[29] K. Browne, D. Roseman, D. Shaller, S. Edgman-Levitan. Analysis \& commentary measuring patient experience as a strategy for improving primary care. Health Affairs. 1, 29[5], pp.921-5, 2010.

[30] J.J. Fenton, A.F. Jerant, K.D. Bertakis, P. Franks. The cost of satisfaction: a national study of patient satisfaction, health care utilization, expenditures, and mortality. Archives of internal medicine. 12, 172[5], pp.405-11, 2012.

[31] V. Velikj-Stefanovska, M. Stefanovska-Petkovska. Patient satisfaction in outpatient healthcare services at secondary 
level vs. tertiary level. Srpski arhiv za celokupno lekarstvo, 142[9-10], pp. 579-85, 2014.

[32] S.Hasan, H. Sulieman, K. Stewart, C.B. Chapman, M. Y.
Hasan, \& D.C. Kong. Assessing patient satisfaction with community pharmacy in the UAE using a newly-validated tool. Research in Social and Administrative Pharmacy, 9(6), 841-850. 2013. 